\title{
Pleistocene Coastal Evolution in the Makran Subduction Zone
}

\author{
Raphaël Normand ${ }^{1 *}$, Guy Simpson ${ }^{1}$ and Abbas Bahroudi ${ }^{2}$ \\ ${ }^{1}$ Department of Earth Sciences, University of Geneva, Geneva, Switzerland, ${ }^{2}$ Exploration Department, School of Mining \\ Engineering, University of Tehran, Tehran, Iran
}

OPEN ACCESS

Edited by:

Daniel Melnick,

Austral University of Chile, Chile

Reviewed by:

Cengiz Yildirim,

Istanbul Technical University, Turkey

Alan S. Trenhaile,

University of Windsor, Canada

Julius Jara-Muñoz,

University of Potsdam, Germany

Kate Clark,

GNS Science, New Zealand

${ }^{*}$ Correspondence:

Raphaël Normand

raphnormand@gmail.com

Specialty section:

This article was submitted to

Quaternary Science, Geomorphology and Paleoenvironment, a section of the journa Frontiers in Earth Science

Received: 29 March 2019 Accepted: 02 July 2019

Published: 31 July 2019

Citation:

Normand $R$, Simpson $G$ and Bahroudi A (2019) Pleistocene Coastal Evolution in the Makran

Subduction Zone.

Front. Earth Sci. 7:186. doi: 10.3389/feart.2019.00186
Along the coast of the Makran subduction zone (SE Iran and SW Pakistan), active uplift combined with efficient erosion and vigorous sediment transport have led to marine terraces with unique morphology and sedimentology. These terraces are characterized by the systematic presence of an extensive 1-10+m thick sandstone layer capping their wave-cut base. Our investigation of thirty-six sedimentary logs of the terrace deposits revealed a general prograding trend from nearshore to beach deposits moving upsection. The presence of a thick marine sedimentary succession above the erosive platform suggests continued creation of accommodation space following carving of the platform by wave-erosion (i.e., erosion of the platform occurred before the peak of the highstand). Deposition of prograding beaches above the platform is interpreted to have occurred during the sea-level stillstand and the start of sea-level fall and was favored by a high sedimentary supply. While some terraces evolve into a classic staircase morphology, others are found as flat-topped platforms bounded by steep cliffs, isolated within the low-lying coastal plain. We find that this morphological difference results from a contrast in bedrock erodability (resistant sandstone versus soft marl, respectively). The flat-topped isolated marine terraces with marl bedrock share morphological and sedimentological similarities with Holocene crenulated beaches currently developing in low-lying bays between headlands. As indurated beaches are uplifted into headlands, they influence the development of following generations of beaches before being eroded by surficial erosion and wave action. Our study shows that the coastal geomorphology of the Makran coast is dictated by the interaction between tectonics (providing relative sea-level fall and juxtaposing units of different erodability at the same structural level by faulting), differential erosion between hard and soft rock (responsible for the presence of isolated headlands) and coastal sedimentary transport processes (permitting accumulation of extensive beach deposits).

Keywords: Makran subduction zone, marine terrace deposits, coastal evolution, differential erosion, uplifted beach, headland bay beach

\section{INTRODUCTION}

Located between the Strait of Hormuz and the Indus Plain, the $900 \mathrm{~km}$-long, east-west trending coast of the Makran subduction zone (Figure 1A) is an ideal natural laboratory to study the coupled interactions between active sedimentation, erosion and tectonics. This is due to the combined effects of several competing factors. First, the region is arid and sparsely vegetated, making its 
geology exceptionally well exposed. Second, the margin is experiencing rapid surface uplift, linked to subduction of the oceanic portion of the Arabian plate beneath the continental Eurasian plate. Third, the subduction zone experiences a high sedimentary input from subaerial portions of the eroding accretionary prism.

Here, we have studied a series of peculiar uplifted marine terrace deposits that reflect these competing phenomena. These terraces are somewhat unusual because they are both erosional and depositional, i.e., they form in response to widespread marine erosion during sea-level highstands, but they are covered with often thick veneers of shallow marine sediment (hereafter referred to as "terrace deposits") that reflect the high sediment input into the coastal region. These terraces are distinctly different from most other marine terraces that are dominantly erosive (e.g., Lajoie, 1986; Anderson et al., 1999; Pedoja et al., 2014). The Makran marine terraces (Mmt) are also intriguing because their preservation and evolution depends sensitively on the nature (erodability) of the local bedrock (i.e., sandstone versus marl).

In this study, we have investigated the morphology and sedimentology of the Mmt using a combination of satellite imagery, DEM analysis, and targeted fieldwork. In another recent study, we have constrained the ages of the terraces using C14, U-Th series and OSL dating (Normand et al., 2019d). Here, we attempt to answer the following questions: What does terrace deposit sedimentology tell us about the coastal setting during previous highstands? Why are the terraces found as isolated platforms or headlands and what controls their distribution along the coast? Which marine terrace definition best suits the Mmt? How did the Makran coast evolve throughout the Late Pleistocene? Ultimately, our study aims to improve our general understanding of interactions between tectonic uplift, eustasy, surface processes and coastal sedimentation.

\section{GEOLOGICAL SETTING}

The area studied sits on the coastal margin in the upper plate of the Makran subduction zone, located in southeastern Iran. At this margin, the oceanic Arabian plate is currently passing northward beneath the continental Eurasian plate at a rate of approximately $2 \mathrm{~cm}$ /year (Figure 1A) (e.g., Vernant et al., 2004; Masson et al., 2007; Khan et al., 2008; Frohling and Szeliga, 2016). Although the Makran subduction zone has low historical seismic activity, especially the western segment (Byrne et al., 1992), tectonic uplift of the prism is evidenced by the presence of numerous marine terraces along the coast (Figure 1C) (e.g., Page et al., 1979; Snead, 1993; Normand et al., 2019d). The thick pile of emerging sediments comprising the prism are Himalaya derived (Harms et al., 1984). However, most sediments on the modern coast are reworked from emerged portions of the accretionary prism residing to the north of the studied area (McCall and Kidd, 1982; Ellouz-Zimmermann et al., 2007; Bourget et al., 2010). Data from offshore sedimentary structures and cores (Uchupi et al., 2002; Bourget et al., 2010), as well as the presence of extensive and fast-prograding Holocene beach ridges successions along the
Makran coast (e.g., Shah-Hosseini et al., 2018; Normand et al., 2019b) evidence a high sedimentary input into the Oman Sea.

The Makran area presently has an arid climate with a low yearly mean precipitation $[\sim 97-127 \mathrm{~mm}$ at the coastline (Sanlaville et al., 1991)] and sparse vegetation cover. Rain events are rare but intense, occurring mainly in winter. These events induce substantial erosion of the soft sedimentary rocks of the prism, river re-activation and flooding of the coastal plain (Stiffe, 1874; Harrison, 1941; Falcon, 1947; Snead, 1967). The tidal range is micro to mesotidal [1.8-2.7 $\mathrm{m}$ (Snead, 1993)]. In the western Makran, waves and wind come mainly from the SSE with significant wave heights of 1 to $3 \mathrm{~m}$ and wave periods between 4 and 8 s (Saket and Etemad-shahidi, 2012).

\section{Geology at the Coastal Makran}

The pre-Quaternary bedrock of the coastal margin in the eastern Iranian Makran consists of sedimentary rocks of Upper Miocene to Pliocene age (Samadian et al., 1994, 1996, 2004; Figure 2). Although these units have formation names in the Pakistani Makran [e.g., Ormara, Chatti, Talar formations (Harms et al., 1984)], correlation with the unnamed formations of the Iranian Makran has not yet been established. The three broad Tertiary units relevant to this paper can be differentiated on the basis of their lithology and age (Figure 2). The base and top of the sequence is made of two formations of Upper Miocene and Pliocene age, respectively (Samadian et al., 1994, 1996, 2004), with a sandstone-dominated lithology. These typically consist of an alternance of sandstones and finer marl layers, that are associated with regression and transgression of the coastline on shallow wave-dominated shelves (Harms et al., 1984). The middle interval (Upper Miocene) is composed of fine-grained slope marl deposits occasionally intercalated with thin sandstone layers (Harms et al., 1984) and incorporating pipes or boudins of orange mudrock (that we suspect are derived from mud volcano activity) as well as gypsum veins (Normand et al., 2019a, Figure M).

These Tertiary sedimentary units are faulted and deformed into wide, gently double-plunging, E-W trending anticlines and synclines, visible in satellite imagery (Figure 2; Farhoudi and Karig, 1977; Leggett and Platt, 1984; Samadian et al., 1994, 1996, 2004). Although reverse faulting is associated with the growth of folds both in the immerged part of the prism (offshore) and north of the coastal region (White and Louden, 1982; Grando and McClay, 2007), normal faults predominate close to the coastline (Ghorashi, 1978; Harms et al., 1984; Platt and Leggett, 1986; Snead, 1993; Dolati and Burg, 2013; Normand et al., 2019b).

The topography of the coastal area is mostly dominated by a flat and wide (about $20 \mathrm{~km}$ ) coastal plain, which contrasts with the rugged morphologies of both the Makran ranges (the name given to the mountains north of the coastal plain) and the coastal headlands hosting Quaternary marine terraces (Figure 1B). Although the coastal plain is mostly covered by a thin veneer of modern fine-grained distal alluvial fan deposits, a few outcrops reveal the nature of the underlying bedrock, which consists predominantly of Upper Miocene gray marls. These rocks are often deeply eroded (forming badland topography), except where they are preserved under layers or debris of indurated Quaternary 


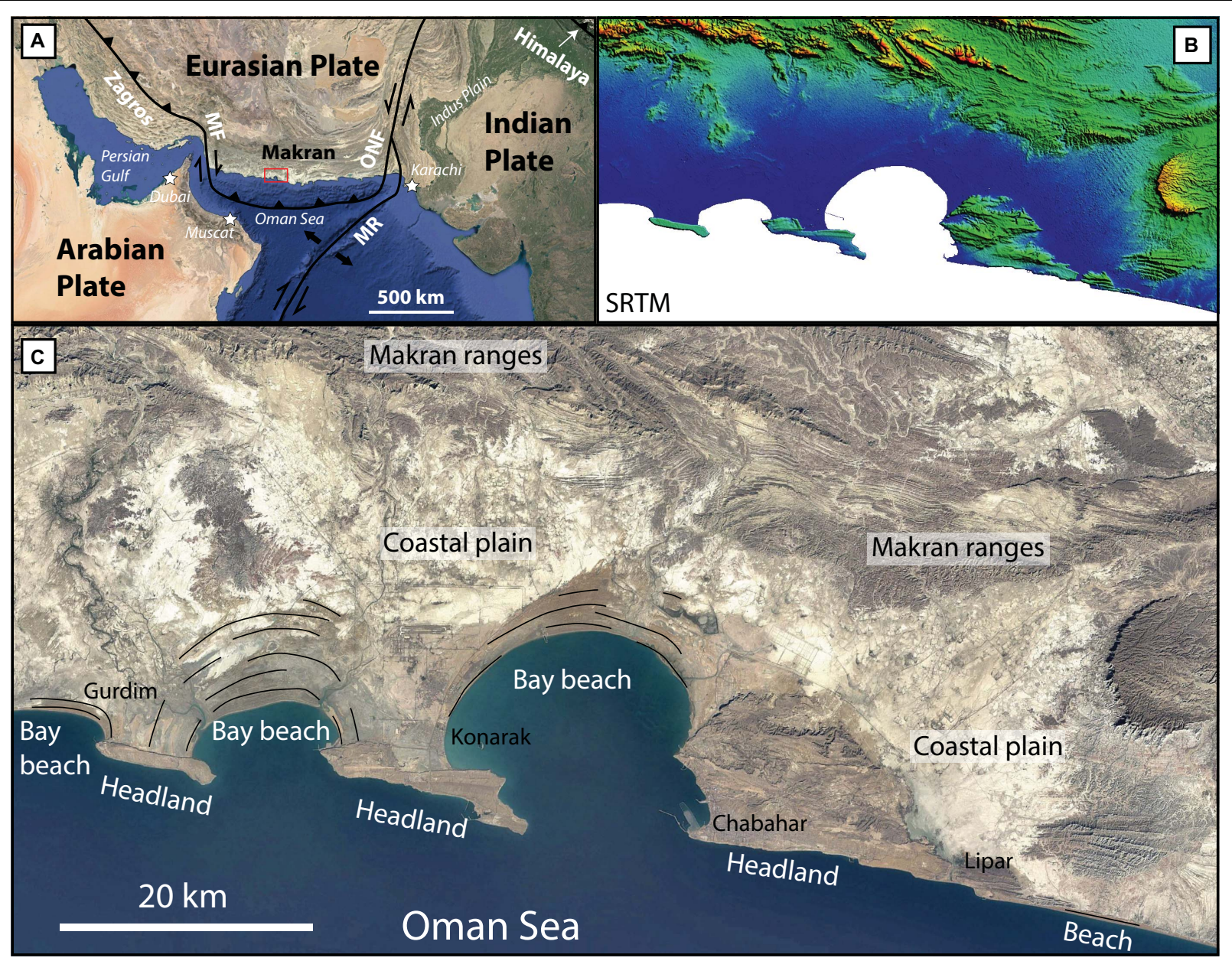

FIGURE 1 | General location of the Makran Subduction zone. (A) Tectonic setting. MF, Minab fault zone; MR, Murray Ridge; ONF, Ornach-Nal fault. (B) Shaded relief (SRTM) image of panel C (dark blue $=0 \mathrm{~m}$, red $=700 \mathrm{~m}$ altitude). Note the flat coastal plain and the protruding headlands at the coastline. (C) Landsat satellite image of a portion of the coastal Makran near Chabahar (SE Iran). Black lines are beach ridges. Black names are localities. Headlands host marine terraces.

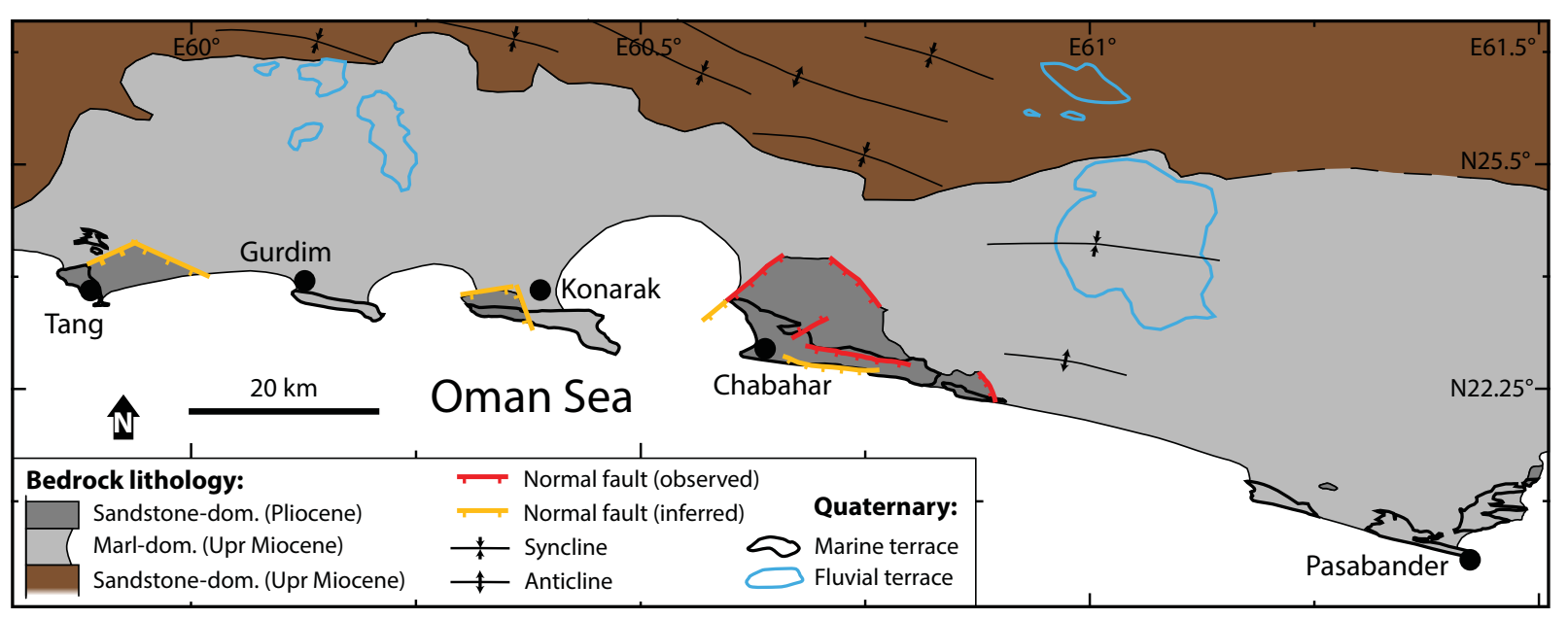

FIGURE 2 | Simplified bedrock lithology map of the Chabahar region, emphasizing location of marl or sandstone dominated lithologies. Except for the Chabahar headland, the Pliocene age of sandstone-dominated outcrops are inferred. 
deposits (marine terraces or fluvial terrace deposits) (Normand et al., 2019a, Figures M, GU, PA, TA).

Numerous normal faults are observed to cut the sediments of the Makran coastal area. These faults strike dominantly parallel to the coast and dip toward the south (or less commonly toward the north). Faults have throws ranging from less than a meter to more than fifty meters. These faults are important for the development and preservation of marine terraces in the region because they can juxtapose units of drastically different erodability to the same structural level (Figure 3). For example, in the vicinity of Chabahar, a series of large headland bounding normal faults have locally juxtaposed easily erodable Upper Miocene marls against relatively resistant Pliocene sandstones (Figure 3). This results in topographic inversion whereby the downthrown block stands high because it is more resistant than the adjacent upthrown marl block (Figure 3). Normal motion on these faults is confirmed by local drag features, Riedel shears and terrace offsets (Normand et al., 2019b,d). Note that although the relative motion between the headland and the coastal plain is due to normal faulting, the general regional trend remains uplift, as attested by the presence of marine terraces on the downfaulted headland. Only the Chabahar headland was directly observed to be bound by normal faults. However, the Tang and Konarak headlands of Tertiary sandstones also show sharp boundaries with the coastal plain, which might also suggest the presence of faults controlling the limits of these headlands (Figure 2).

Along the seaward margin of the coastal plain, two types of protruding headlands are found. While the first are these localized outcrops of sandstone-dominated bedrock, the second are high, flat platforms, characterized by a planar layer of marine terrace deposits capping gray marl bedrock (more details in see section "Terrace Morphology"). Between the protruding headlands, the coastline has developed into deep bays hosting extensive successions of beach ridges (Figure 1), deposited since the Holocene maximum transgression (Gharibreza, 2016; Shah-Hosseini et al., 2018; Normand et al., 2019c).

\section{MARINE TERRACES: GENERAL DEFINITIONS}

Marine terraces are geomorphic features found along coastlines subject to relative sea-level changes (Lajoie, 1986). Marine terraces can be divided into three broad categories: constructional, erosional and depositional terraces. Constructional terraces are formed mainly by coral reef development and are not considered further here since the Makran coast rarely hosts coral constructions.

Erosional wave-cut platforms are planar surfaces incised by wave action into the underlying bedrock. Through the combined effects of eustasy and tectonics, these surfaces may be emerged, after which time they start to degrade by weathering and erosion while younger surfaces develop in a lower position (Anderson et al., 1999). Because the erosive energy available at the base of a sea cliff is reduced as the wave power dissipates across an expanding platform, the development of platforms becomes increasingly difficult as they widen (e.g., Trenhaile, 2000,
2014; Limber et al., 2014). Modeling has highlighted a range of parameters that control platform width, including strength (resistance) of the bedrock, the presence of debris protecting the cliff foot, the tidal range and the duration of the sea-level stillstand (e.g., Anderson et al., 1999; Trenhaile, 2000, 2002). Moreover, because younger terraces develop at the expense of older ones, some terrace levels might be entirely erased from the geomorphic record (e.g., Trenhaile, 2014). Numerical models of shore development have shown that erosion is more effective during episodes of relative sea-level rise than fall (e.g., Trenhaile, 2002). The presence of a beach on the platform can accelerate or reduce coastal retreat, depending on the amount of sediments on the platform (e.g., Limber et al., 2014; Trenhaile, 2016, 2018).

Depositional terraces are often named wave-built terraces, but this term has been used to describe a variety of different coastal landforms, without a clear definition (Dietz, 1963). The term was originally defined by Gilbert (1890) to describe paleobeach ridge successions around Lake Bonneville. It was subsequently traditionally re-used to characterize subaqueous platforms, created by sedimentary accumulation at the seaward edge of a wave-cut platform (Dietz, 1963; Bird, 2000). The latter, observed in modern coastline settings, are rarely preserved in the fossil record (Dietz, 1963). Following the original idea of Gilbert (1890), Jara-Muñoz and Melnick (2015) have defined wave-built marine terraces as stacked patterns of sediments deposited above a wave-cut platform. The succession of sediment-covered terraces are therefore often characterized by a smooth topographic expression as the relief of shoreline angles are partially covered by sediments. The difference with a wave-cut platform covered by sediments is that the sedimentary succession of a wave-built terrace has a certain degree of complexity in its sedimentary succession. The nomenclature of entirely depositional or mixed erosional/depositional marine terraces remains ambiguous.

\section{THE MAKRAN MARINE TERRACES}

Along the Makran coast, the Tertiary basement units are commonly overlain by extensive marine terraces. These terraces are typically characterized by a 1-10 m thick shelly sandstone deposits that cap the underlying basement sediments along a wave-cut unconformity (Falcon, 1947; Little, 1972; Page et al., 1979; Snead, 1993). The sedimentary succession of the terrace deposits has been described as beach deposits (Falcon, 1947; Vita-Finzi, 1980; Snead, 1993), though only a few detailed sedimentary sections have been previously described (Little, 1972; Normand et al., 2019d). Some authors have argued that a few terraces, showing sharp linear edges parallel to the coastline (e.g., Konarak, Gurdim), might have developed on horsts (Little, 1972; Snead, 1993).

The necessity of widespread and accurate dating of the Mmt in order to derive surface uplift rates has been pointed out by VitaFinzi (1980). Most previous dating attempts on the Mmt were done by radiocarbon dating of shells sampled within the terrace deposits, which yielded ages greater than $20 \mathrm{ka}$, interpreted as minimum ages (see Normand et al., 2019d and references therein). Recently, OSL dating of the Iranian (western) Makran 

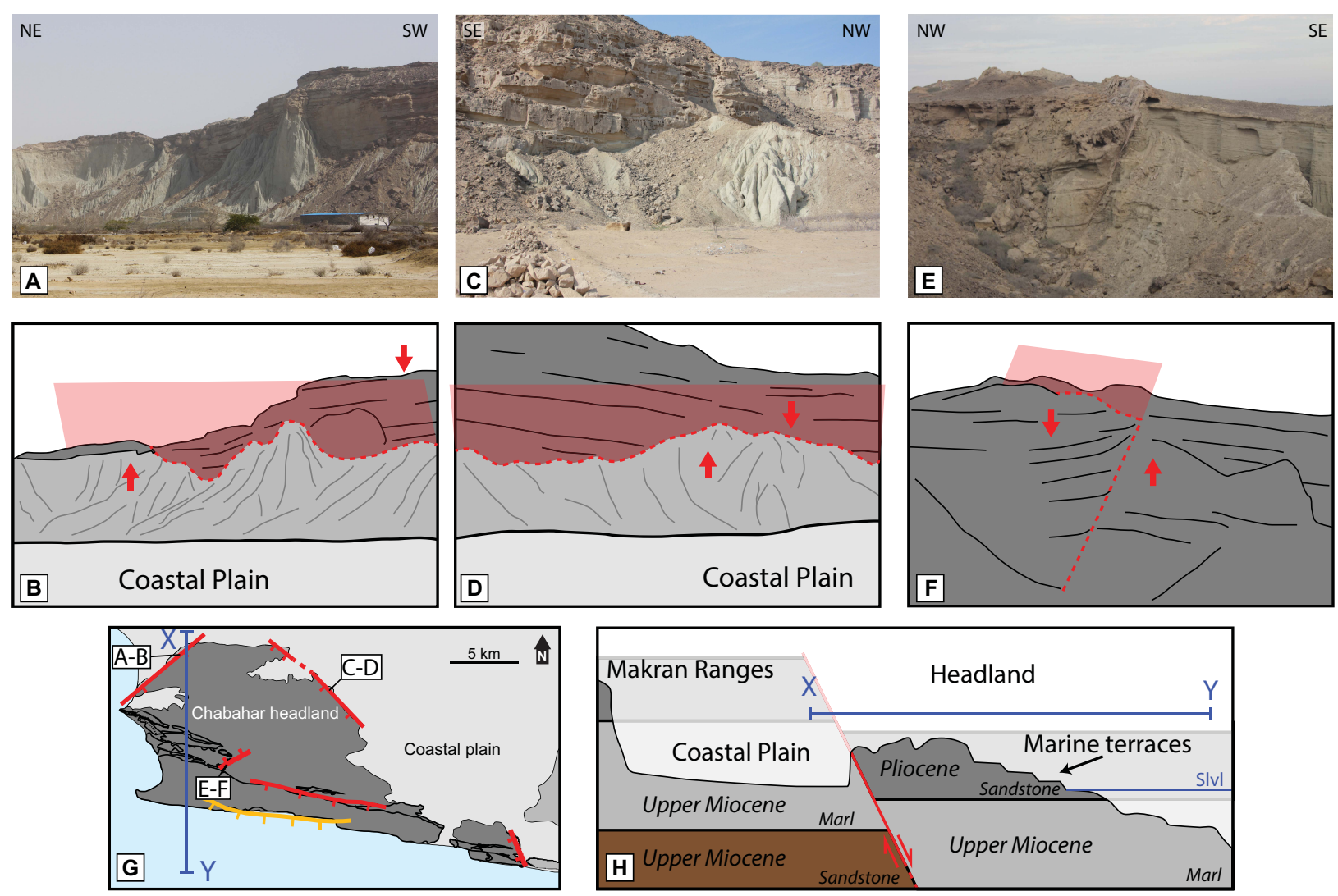

FIGURE 3 | Major normal faults bordering the Chabahar headland. (A-D) Photo and sketch of the outcropping faults. The low-lying coastal plain sits in the uplifted block, whereas the headland is downthrown. (E,F) A major normal fault outcropping within the headland. (G) Localization of the major normal faults of Chabahar headland (red). Orange fault is inferred. (H) Sketch of a profile from the Makran ranges to the sea, going through a downfaulted headland (as in profile X-Y in panel G). Tectonic deformation of the Tertiary layers is ignored for simplicity.

terraces has permitted the correlation of the marine terrace sequences to past sea-level highstands. The results revealed that most marine terraces formed between MIS5 (75-126 ka) and MIS 17 ( $\sim 700 \mathrm{ka})$, with two very young surfaces dated at MIS3 (30-50 ka) (Normand et al., 2019d). Calculation of uplift rates revealed moderate to high uplift rates along the Iranian Makran coast $\left(0.05-1.5 \mathrm{~mm} \mathrm{y}^{-1}\right)$. An exceptionally high uplift rate of up to $5 \mathrm{~mm} \mathrm{y}^{-1}$ was calculated in Pasabander area, close to the border with Pakistan, however, this anomalous result remains problematic (Normand et al., 2019d). Dating of the marine terraces and their implication for geodynamics is not the focus of this paper, though knowledge of their age is important, especially from a geomorphological point of view.

\section{Terrace Morphology}

Our study of the Mmt revealed two distinctive terrace morphologies, based on the nature of the bedrock into which the terrace was carved (indurated sandstone-dominated lithology versus erodible marl-dominated lithology). Terraces that developed on sandstone-dominated headlands (hereafter referred to as sandstone-type terraces) have a classic staircase morphology that reflects recent trends of relative sea-level change (Figure 4A; Lajoie, 1986; Anderson et al., 1999; Trenhaile, 2002).
Sequences of such terraces are relatively extensive, with 6+ levels in Chabahar, possibly ranging back to MIS 17 (Normand et al., 2019d). Each terrace is generally backed by a paleocliff (that can be topped by an older terrace) at the base of which fossil rockfall megaboulders are sometimes found embedded within the terrace deposits (Figure 4B; Normand et al., 2019d). While the bedrock bedding is most of the time tilted owing to prism deformation (e.g., Figures 4B,F), subhorizontal resistant Tertiary sandstone beds sometimes closely resemble marine terraces (Snead, 1993).

Terraces found on marl-dominated bedrock (hereafter referred to as marl-type terraces) have a singular morphology (Figure 4F). They are wide platforms (up to $5 \mathrm{~km}$ ) bounded by steep cliffs carved within the marl bedrock and capped by terrace deposits (Figures 4C,F). Most of the time, the paleocliff backing the terrace is degraded into badlands (covered with debris of terrace deposits) or is entirely absent (eroded down to the level of the coastal plain, Figures 4C,D,F). Surficial erosion (rain gathering into streams) seems to be the main factor eroding the marls as gully morphologies are seen forming the badlands and cutting through the terrace deposits (Figures 3, 4C,D). Sequences of such terraces comprises up to four levels, the upper levels being highly degraded into isolated platforms less than a square kilometer in area. Dating results from marl-type terraces show 

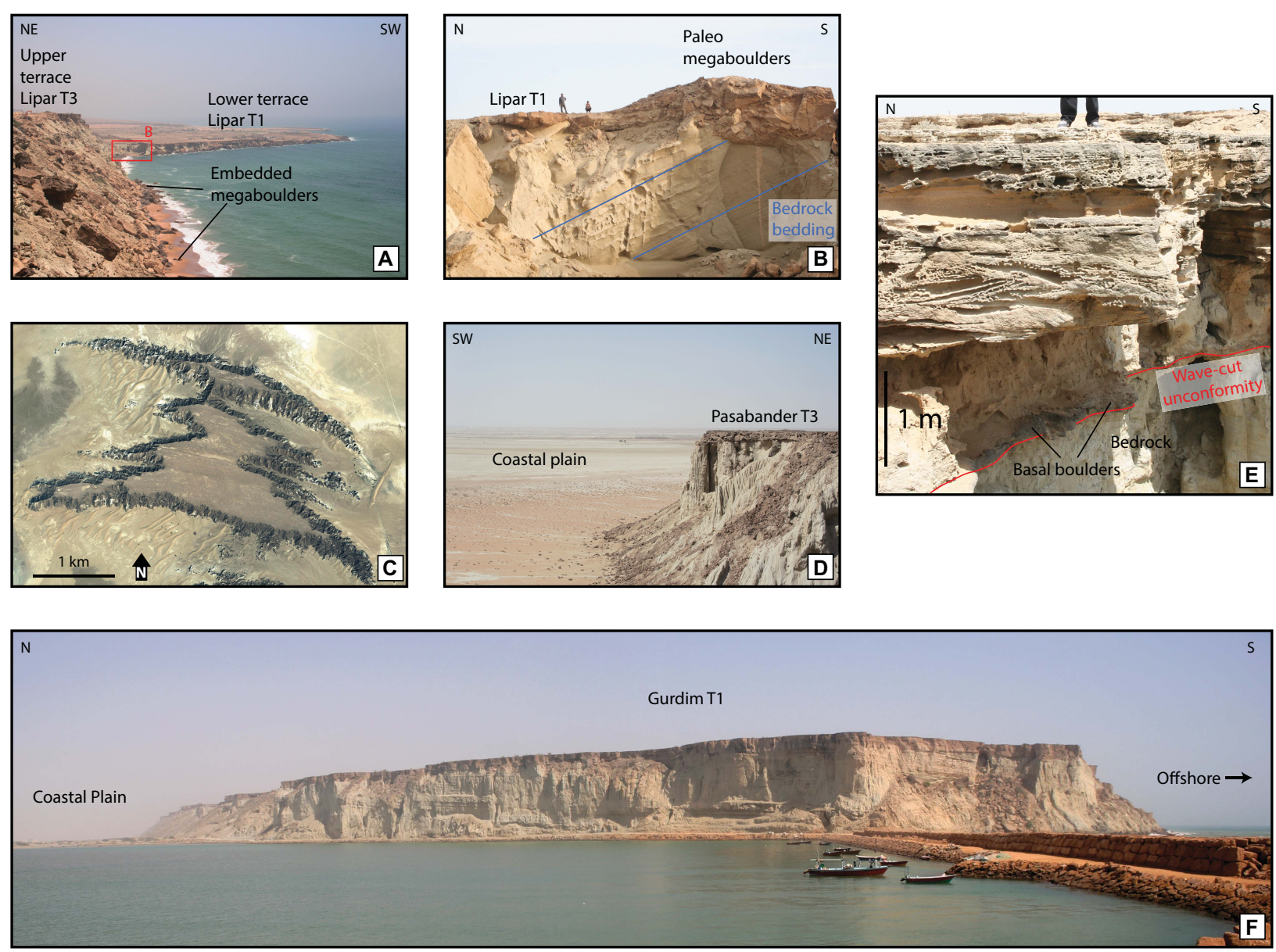

FIGURE 4 | Figures illustrating the Mmt geomorphology and sedimentology. More pictures may be found in Normand et al. (2019a). (A) General view of sandstone-dominated terraces, which have a classic staircase morphology. Here, two terraces of Lipar T1 and T3 are separated by a paleocliff. The Holocene platform is being carved through both T1 and T3 and megaboulders are seen embedded in the small Holocene beach at the feet of T3. T3 is $60 \mathrm{~m}$ high. Red square is the position of panel $\mathbf{B}\left(25.250^{\circ} \mathrm{N}, 60.839^{\circ} \mathrm{E}\right.$; looking SE). (B) Close up of the vicinity of the Lipar T1 shoreline angle. Notice the angular unconformity with the bedrock bedding (blue lines) and the fossil version of embedded megaboulders at the foot of the paleocliff (which is situated a few meters to the left of the picture) $\left(25.247^{\circ} \mathrm{N}, 60.848^{\circ} \mathrm{E}\right)$. (C) Google Earth satellite image of Tang T3, illustrating some morphological properties of marl-type terraces, such as the isolated platform morphology, the finger-like protrusion and the curved aspect, emphasized by lineations on the terrace surface (see also Figure 8 G) $\left(25.42^{\circ} \mathrm{N}, 59.88^{\circ} \mathrm{E}\right)$. (D) Northern side of Pasabander T3. Note the absence of paleocliff and the highly degraded marl bedrock where unprotected by the terrace deposits $\left(25.134^{\circ} \mathrm{N}, 61.449^{\circ} \mathrm{E}\right)$. (E) Example of terrace deposit succession (here, section P8 of Figure $6 \mathbf{A})\left(25.077909^{\circ} \mathrm{N}, 61.354360^{\circ} \mathrm{E}\right)$. (F) Gurdim terrace seen from its westernmost side. This terrace is one of the best examples of an isolated flat-topped platform. The bedrock is marl, south dipping at a low angle, which emphasizes the angular unconformity with the overlying terrace deposits. The paleocliff, expected in the north of the picture, is absent.

relatively young ages, with some terraces attributed to MIS 3 (e.g., in Pasabander region) and potentially going back to maximum MIS 5e, for the most degraded surfaces (Normand et al., 2019d).

Some terraces (mostly marl-type) have peculiar curved borders, not parallel to the general trend of the modern coastline. This curved morphology is also expressed and accentuated by lineations visible in satellite imagery on those terraces' surfaces (Figure 4C, see also Figure 8G). Field investigation of the linear markers revealed that they are the morphological expression of the top of the terrace deposits composed of gently dipping sandstone sedimentary structures (Normand et al., 2019a, Figures PA5-6). Another geomorphological characteristic of these terraces is their peculiar "finger-like" protrusions in map view (Figure 4C). This morphology, defined by Little (1972), is interpreted to be caused by stream erosion following the trend of the aforementioned lineations (Figure 4C).

\section{Terrace Sedimentology}

All Iranian [and seemingly Pakistani (Snead, 1967, 1993)] Mmt share a common characteristic: They are capped by a layer of marine sediments of thickness varying between 1 and $10 \mathrm{~m}$ (possibly thicker in the eastern Makran) (Figures 4D-F). Thirty six sections of the Iranian marine terrace deposits were logged in order to understand the processes responsible for the deposition of these layers (Supplementary Table S1). Localities were chosen based on their accessibility, but also with the objective of collecting information from the back of the terrace (near the shoreline angle), the middle and the seaward edge of the 
terrace, to understand lateral variability in the sedimentology (Figure 6A). We divide the sedimentary logs into broad facies (Table 1), based on grain-size and sedimentary structures, while the vertical relationships between facies are reported in Figure 6A (Figure 5 contains the log legends).

All studied Makran terrace deposits follow the same general sedimentological trend. The transition between Tertiary bedrock and marine terrace deposits is an erosive surface, normally evidenced by an angular unconformity (e.g., Figures 4A,B). Direct access to the full extent of the erosive surface is prevented by the presence of the terrace deposits, though flatness and continuity of this surface can be estimated from natural sections provided at the terraces' borders (Figure 4F). Although the original thickness of the terrace deposits might have been reduced by erosional processes, we did not detect any systematic thickening nor thinning of the terrace deposits on a transect perpendicular to the coastline (Figure 6A). The base of the terrace deposits frequently incorporates sandstone boulders and pebbles $(\sim 5-50 \mathrm{~cm}$ diameter, some of which are bored by lithophaga mollusks) embedded within the overlying deposit (Figures 4E, 6A). At the back of those terraces backed by a paleocliff, megaboulders (rockfall, of 0.5 to $3 \mathrm{~m}+$ diameter) are found embedded in the terrace deposits (Figure 4B; Normand et al., 2019a). Forming the main body of the terrace deposits, sandy material and shell fragments are arranged into sedimentary structures, such as trough cross stratification (usually at the base of the deposits) and horizontal laminations (usually topping the section) (Table 1) (e.g., Figure 4E). Some sections situated close to river mouths incorporate conglomerate layers. We report the possible occurrences of erosive surface within the stratigraphy of the terrace deposits, although these are difficult to ascertain (Figure 6A, section R9, R10).

\section{Depositional Facies Interpretation}

The type of sediments comprising the terrace deposits are independent of their bedrock type. The presence of boulders and pebbles at the base of many logs, is interpreted as lag deposits associated with a transgressive ravinement surface (i.e., the wavecut platform) (Catuneanu et al., 2011). The recurring occurrence of megaboulders embedded at the back of some terraces implies a certain degree of cliff foot protection as sedimentation starts. The lower sandy units incorporating trough cross-stratifications or other evidences of energetic currents are interpreted as shoreface deposits, whereas the overlying sandy laminated facies is interpreted to be deposited in the swash zone (Table 1) (e.g., Tamura, 2012; Normand et al., 2019c). Eolian deposits are rarely preserved (only in log K1). In summary, the general trend is one of shallowing upward, with all logs evolving from shoreface at the base to foreshore at the top (Figure 6). This suggests a progradational stacking pattern of the sedimentary sequences.

While the general shallowing upward trend described above is true for all logged transects, some incorporate other sedimentological complexities. Conglomerate layers within some terrace deposits (intercalated with shoreface facies) (Figure 6A) are interpreted as mouth bar deposits (related to local river discharge). A fine-grained, non-laminated facies is observed at the base of some logs, just above the wave-cut platform.
This indicates the presence of lagoonal systems at the coastline during the early stages of the highstand. Similar observations were made from Holocene successions in the Makran, where early Holocene ( $8 \mathrm{ka}-6 \mathrm{ka}$ ) lagoonal deposits are found at the base of post-mid-Holocene highstand sandy beach successions (Sanlaville et al., 1991; Normand et al., 2019c). Erosive surfaces within logs of Ramin T1 (R9, R10) are related to episodes of re-occupation of the lower, seaward parts of the platform (e.g., Jara-Muñoz and Melnick, 2015).

\section{Modern Equivalents}

Our interpretation for the coastal evolution of the Makran coastline (see section "Depositional Model") is inspired by the modern coastal depositional setting which is also heavily dictated by bedrock erodability (Normand et al., 2019c). Segments of the coast carved into sandstone dominated lithologies (headlands) usually host narrow beaches $(0-200 \mathrm{~m})$ at the base of their cliff (Normand et al., 2019a, Figure HB). We expect that they behave like the "beaches with resistant foundations" described in Trenhaile (2018). Unfortunately, we do not have information on the subaqueous platform width or on beach thickness. A fine layer of sandy deposits on a rocky platform can serve as an abrasive medium to accelerate cliff retreat. However, the observed Makran headland beaches are often thick and are expected to hinder erosion (Limber and Murray, 2011; Trenhaile, 2016). Fallen boulder blocks and debris often found embedded at the base of the modern cliff (e.g., Figure 4A) also contributes to reduce coastal retreat.

On the other hand, the Makran coastal segment characterized by soft marl bedrock host wide succession of beach ridges (Gharibreza, 2016; Shah-Hosseini et al., 2018; Normand et al., 2019c). These bay beaches are usually crenulated following the dominating wave direction (e.g., Hurst et al., 2015; Normand et al., 2019c). Dating results revealed that the oldest beach ridges, situated near the back of the bays, were deposited during the Holocene maximum transgression, around 6000 years ago. Thus, in these regions the coast has propagated laterally by

Logs legend
$\begin{aligned} & \text { Through cross } \\ & \text { stratifications } \\ & \text { Parallel, low angle } \\ & \text { stratification } \\ & \text { High angle cross } \\ & \text { stratifications } \\ & \text { Meter(s) sized } \\ & \text { megaboulder(s) }\end{aligned}$
Erosive surface




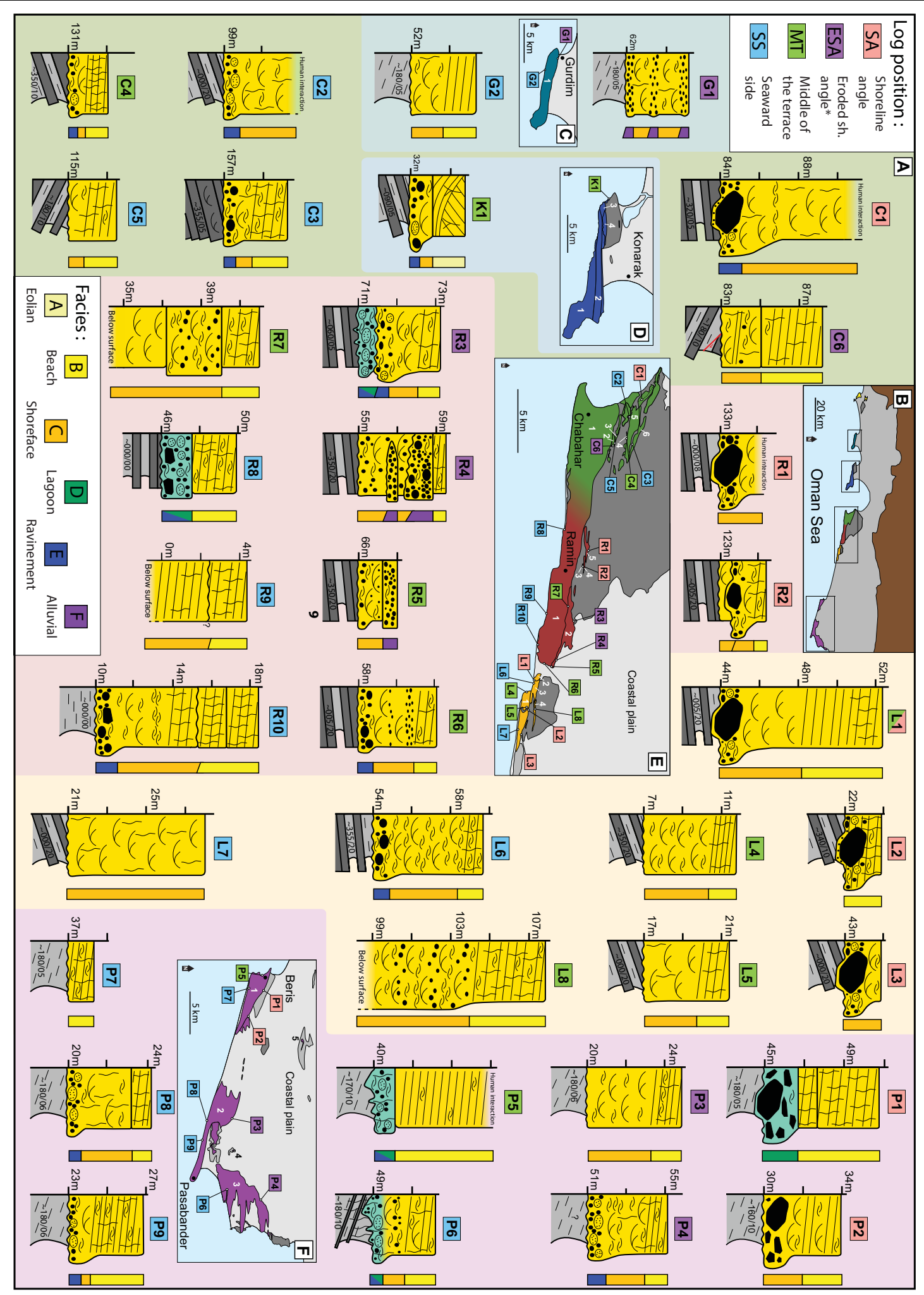

FIGURE 6 | Sedimentary logs of the terrace deposits and their location. Outcrop pictures of such logs are reported in the data repository (Normand et al., 2019a). (A) Sedimentary logs, arranged from shoreline angle (top of the picture) to seaward side (bottom). Colors of the background correspond to the terrace region from which they were measured (see maps). Legends are found in Figure 5. *Eroded shoreline angle (ESA): Logged at the back of the terrace, when the paleocliff (and the shoreline angle) is eroded (e.g., Figures 4D,F). (B-F) Localization of the logs of Gurdim (turquoise), Konarak (blue), Chabahar (green), Ramin (red), Lipar (yellow), and Pasabander (purple). 

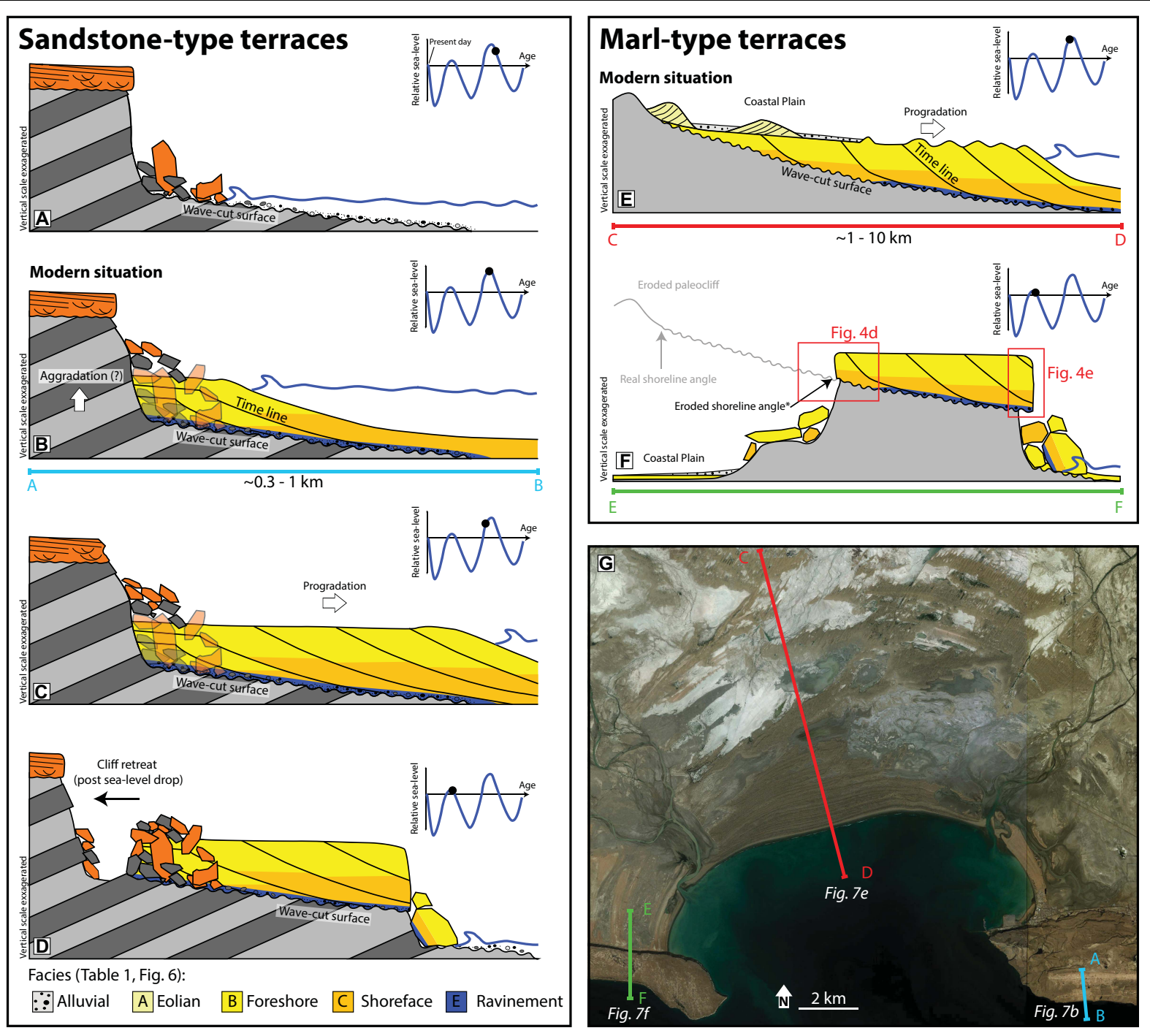

FIGURE 7 | Interpretation of the Mmt development as sea-level varied through time. (A-D) Model for sandstone-type terraces. (A) Start of the highstand, carving of the wave-cut platform. (B) Post-peak of the highstand, start of beach deposition, as seen currently in the Makran headland beaches (e.g., Figure 4A foreground). (C) End of highstand, start of sea-level fall. Rapid beach progradation across the shallow platform. (D) Next highstand, after relative sea-level fall, the paleobeach is now found as a marine terrace. The paleocliff seems to be eroding further after platform abandonment, as its current position can be a few tens of meters from the megaboulders delineating the original position of the shoreline angle (Normand et al., 2019a, images CH5-6 and LI4). (E,F) Model for marl-type marine terraces. (E) After platform carving into the soft marl, the bay beach develops in a series of prograding beach ridges, as seen currently along the Makran (e.g., Figures 1, 7G). Note the difference in lateral extension compared to sandstone-type terraces. (F) Situation at the next highstand, the beach is uplifted into a marine terrace (e.g.,

Figures 4B,F). (G) Satellite image (Bing) of Pozm bay and surroundings, illustrating modern equivalents of some of these sketches. More examples illustrating these profiles in Figures $\mathbf{8}, \mathbf{9}$.

several kilometers over the last few 1000 years at rates of up to $5 \mathrm{~m} / \mathrm{yr}$ (meter per year) (e.g., Gharibreza, 2016; Normand et al., 2019c). These results emphasize vigorous sediment activity along the Makran coast.

\section{DISCUSSION}

\section{Depositional Model}

Observations of the terrace deposits and the modern coastline led us to the following depositional model (Figure 7). Carving of the platform seems to have occurred during the early stages of the sea-level highstand (associated with sea-level rise) and carried on until wave-energy was insufficient to further extend the platform (e.g., Anderson et al., 1999; Trenhaile, 2002; Figure 7A). The platform width was presumably partially controlled by the erodability of the bedrock (e.g., Trenhaile, 2014), since marl-type terraces are notably wider than sandstone-type terraces.

The thickness of the terrace deposits (up to $10 \mathrm{~m}$, even at the back of the terrace, Figure 6A) attests the continued creation of accommodation space following the carving of the shoreline angle. Hence, we suggest that most platform erosion occurs 

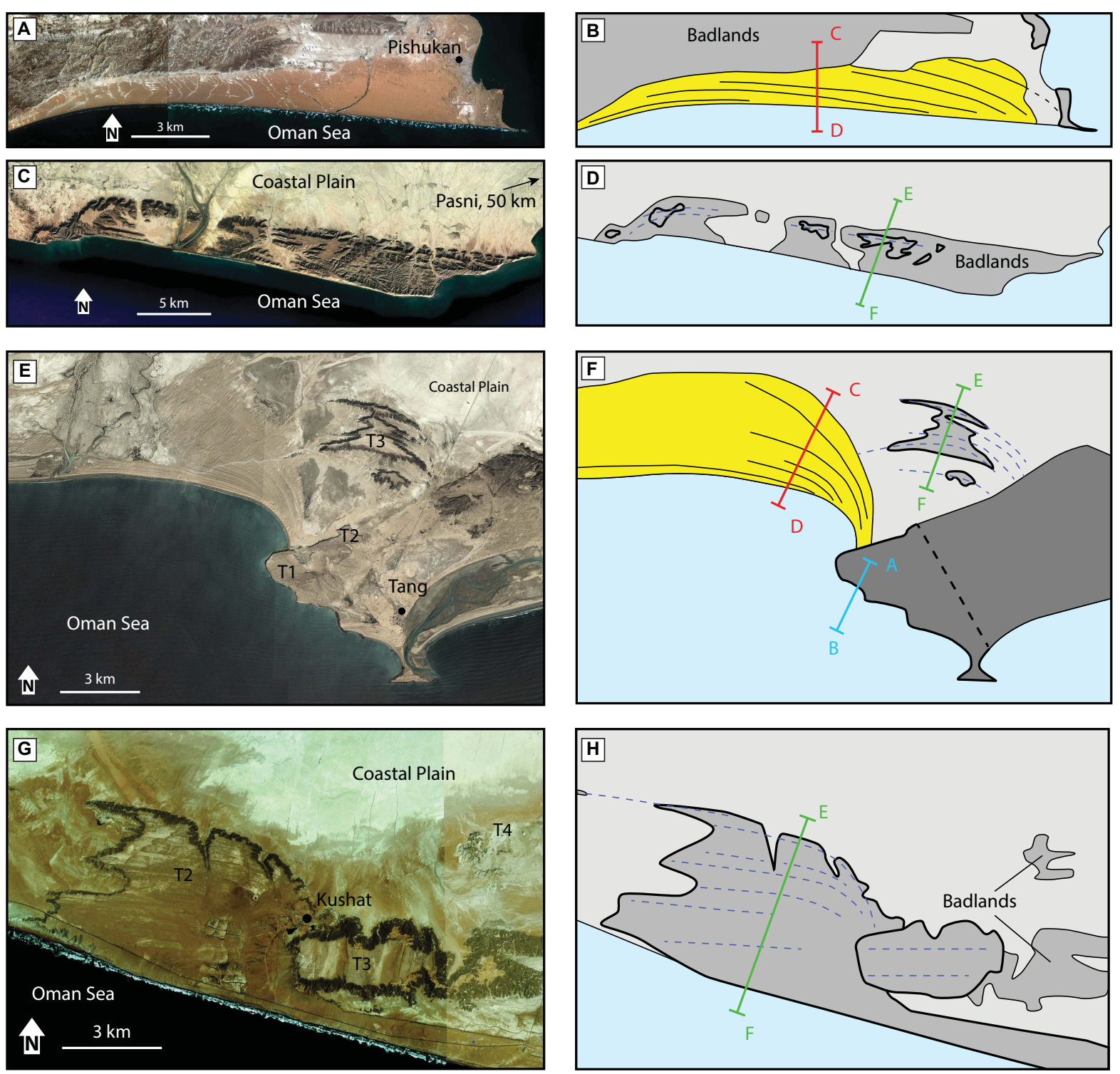

Legend:

Pleistocene

$\curvearrowright$ Marine terrace

- - Paleo beach ridge
Holocene cover

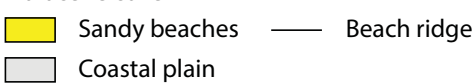

FIGURE 8 | Marl-type beaches and terraces. Colored profiles are the sketches from Figure 7. (A,B) Pishukan beach (Pakistan), a Holocene bay beach built on marl bedrock. Notice the sharp northern beach limit carved by wave erosion. (C,D) Ras Shamal Bandar, a terrace $\sim 50 \mathrm{~km}$ west of the village of Pasni (Pakistan). Notice the morphological similarities with Pishukan beach pictured in panel $\mathbf{A}$, though here, the paleocliff and badlands beyond are eroded down to the coastal plain level. $\mathbf{( E , F ) ~ T a n g ~ t e r r a c e s . ~ T 3 ~ i s ~ a n ~ u p l i f t e d ~ v e r s i o n ~ o f ~ t h e ~ n e a r b y ~ H o l o c e n e ~ b e a c h ~ ( y e l l o w ~ i n ~ p a n e l ~} \mathbf{F}$ ), notice the morphological similarities. The Holocene beach is deposited in the leer of T1. T3 was created in a similar fashion, by wave-diffraction around a rocky headland (probably the one outcropping in the east of the picture). (G,H) Pasabander marl-type terraces; T2, T3 and T4. The morphology of T2 is similar to the crenulated Holocene bay beaches (e.g., Figures 7G, 8E), and was probably built by wave-diffraction around T3. F,H inspired from the maps of Normand et al. (2019d).

during the early stages of a sea-level highstand (i.e., during sea-level rise). The first sedimentary layers, deposited near the shoreline angle and above the wave-cut surface are expected to be aggradational (Figure 7B). Another hypothesis is that the beach profile readjusts to account for relative sea-level rise, forming a thicker but less extensive berm at the base of the cliff, as proposed by Trenhaile (2018). A more detailed analysis of the sedimentary successions near the shoreline angle of the uplifted terraces is necessary to resolve this matter. The middle to late stages of the highstand are dominated by shallowing-upward sedimentation, as prograding beaches develop above the wave-cut surface due to the high sedimentary input along the Makran coast combined with relative sea-level fall (Figures 6A, 7C,E). This last phase differentiates the $\mathrm{Mmt}$ from most marine terraces in other parts 
TABLE 1 | Facies encountered in the western Mmt sedimentary successions.

\begin{tabular}{|c|c|c|c|c|c|}
\hline Facies & $\begin{array}{l}\text { Matrix } \\
\text { grain-size }\end{array}$ & Bioclasts & Other clasts & Support & Sedimentary structures \\
\hline A & Sand & Roots & & Matrix-supp. & High angle, large cross strat. \\
\hline B & Sand & Shells or shell fragments & A few small pebbles & Matrix-supp. & $\begin{array}{l}\text { Horizontal lamination. Some } \\
\text { small scale trough cross strat. }\end{array}$ \\
\hline C & Sand & Shells or shell fragments & A few pebbles & Matrix-supp. & Trough cross strat., foresets \\
\hline D & Silt to clay & Shells or shell fragments & Pebbles, bored pebbles & Matrix-supp. & None \\
\hline $\mathbf{E}$ & Sand to clay & Shell fragments & 10-50 cm boulders, pebbles & Clast-supp. & None \\
\hline $\mathbf{F}$ & Sand & Shell fragments & Pebbles (1-8 cm diamater) & Both & None, or pebbles imbrication \\
\hline Facies & Biorturbation & Sorting & Others & Interpretation & \\
\hline A & $\begin{array}{l}\text { Tubular } \\
\text { burrows }\end{array}$ & Very good & Rarerly observed (1 occurrence) & Eolian & \\
\hline B & $\begin{array}{l}\text { Tubular } \\
\text { burrows }\end{array}$ & Good & $\begin{array}{l}\text { Laminations gently sloping } \\
\text { toward the sea }\end{array}$ & Beach / swash deposits & \\
\hline C & None & Good & High energy deposits & $\begin{array}{l}\text { Wave-influenced, energetic } \\
\text { environment / Shoreface }\end{array}$ & \\
\hline D & Important & Bad & & Lagoonal deposits & \\
\hline E & None & Very bad & Bored pebbles & $\begin{array}{l}\text { Transgressive surface } \\
\text { (ravinement) }\end{array}$ & \\
\hline $\mathbf{F}$ & None & Bad & $\begin{array}{l}\text { Pebble rich deposit, both } \\
\text { occurrences of clast and matrix } \\
\text { supported }\end{array}$ & $\begin{array}{l}\text { River influenced deposit } \\
\text { (mouth bar?) }\end{array}$ & \\
\hline
\end{tabular}

of the world, which are usually either uncovered or capped by only a thin veneer of colluvium [with some exceptions (e.g., Dupré, 1984; Jara-Muñoz and Melnick, 2015)].

Modern headland beaches are narrow compared to sandstonetype marine terraces. One possible explanation for this difference is that the platform is currently underwater and will be covered during the later stages of the Holocene highstand, as sea-level falls (Figure 7C). Another hypothesis is that the exceptionally wide sandstone-terraces of Chabahar headland (up to $4 \mathrm{~km}$ ) are the result of platform reoccupation during successive highstands as suggested by dating results (MIS 5a and MIS 5e deposits on the same platform) and the flooding surfaces interpreted within the deposits of the lower terrace [R9 and R10 in Figure 6, see also Figure 10 in Normand et al. (2019d)].

There are several sedimentological and morphological parallels between modern bay beaches and the deposits of the marl-type terraces (Figure 8). For example, both comprise prograding, shallowing upward sequences (Page et al., 1979; Vita-Finzi, 1980; Sanlaville et al., 1991; Normand et al., 2019c), although, the Holocene beach sequences contain much more fine-grained (lagoonal) deposits than the older terrace deposits (Sanlaville et al., 1991; Normand et al., 2019c). The curved shaped terraces with finger-like morphologies (e.g., T3 in Figure 8E and T2 in Figure 8G) closely resemble the Holocene crenulated bay beaches that develop in the sections of the coastline with erodible marl bedrock (e.g., Figure 7G and the beach colored in yellow in Figures 8E,F; Yasso, 1965; Valvo et al., 2006; Limber et al., 2014; Hurst et al., 2015; Normand et al., 2019c). Parallel curved lineations observed on the surface of the terraces in satellite imagery are the surficial expression of gently sloping swash planar laminations within the terrace deposits (Normand et al., 2019a, Figures PA5-6). These are therefore, parallel to the paleocoastlines. Moreover, most of the time, the curved lineations on marine terraces are associated with a paleo-headland in the form of a higher terrace, or a sandstone bedrock outcrop (e.g., Tang terraces; Figures 8E,F, Pasab and er T2 and T3; Figures 8G,H). Hence, we interpret that the peculiar isolated marl-type terraces are the uplifted and degraded equivalent of modern bay-beaches (see section "Differential Erosion") (Figures 7E,F). During the early stages of a highstand, a wide and shallow platform is carved into the marl bedrock. Owing to high sedimentation, relative sea-level fall and the small accommodation space available, beach progradation above the platform can reach important rates as seen in the Holocene (Figure 7E).

In summary, we believe that the Mmt develop by wave-cut incision during the early stages of a sea-level highstand, as the sea re-occupies the coastal area. At the maximum transgression and during the relative sea-level fall that follows, coverage of the platform by prograding marine coastal sedimentation, such as beach, lagoonal and other nearshore deposits is favored by active sedimentation and tectonic uplift (Figure 7). This interpretation (based on observations) would benefit from validation or refutation by accurately dating specific levels within the terrace deposits. However, precise dating of individual layers within a Pleistocene sedimentary sequence spanning $10-40 \mathrm{ka}$ is challenging considering the accuracy of existing Quaternary dating methods.

\section{Characterization of the Makran Marine Terraces}

Although the marl and sandstone-type terraces exhibit different geomorphological aspects, all $\mathrm{Mmt}$ are composed of a wavecut surface above which a prograding beach sedimentary 


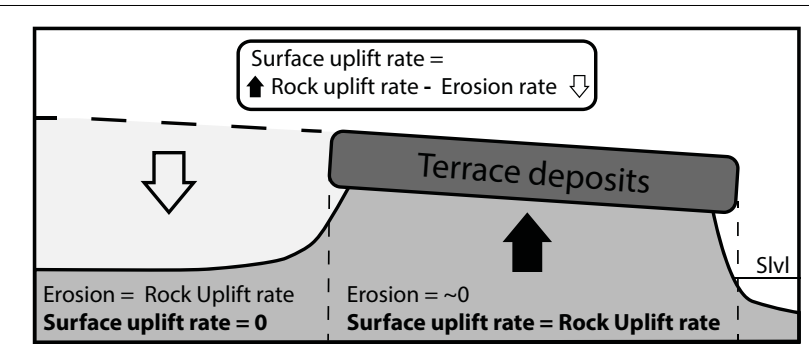

FIGURE 9 | Differential erosion of the marl-bedrock marine terraces and the implications for surface uplift rates. SIvl = sea level. Vertical scale exaggerated.

succession is deposited. Their characteristics are both erosional and depositional. In this respect, they cannot be defined as pure wave-cut terraces. As seen in the section "Marine Terraces: General Definitions," the term wave-built marine terraces has been used to describe several different coastal landforms, not always corresponding to the Mmt. However, the marl-type terraces share exactly the same structures that inspired the original definition of Gilbert (1890), i.e., prograding beach ridges deposited above a wave-cut surface.

According to Jara-Muñoz and Melnick (2015), wave-built marine terraces are stacked patterns of sediments deposited above a wave-cut platform. They also suggest that headlands (exposed to wave attack) are more prone to develop into wave-cut terraces, while embayments (favoring sediment accumulation) would host wave-built terraces. We believe the term wave-built marine terraces is not ideal as it has been used in a variety of setting. However, the Mmt fit this definition and support these suggestions; although headland (sandstone-type) terraces of the Makran also include a stacked pattern of sediments above their wave-cut surface (a characteristic of all Makran terraces), it is manifest that marl-type terraces used to be relatively more extensive and had well developed beaches compared to their headland counterparts. This is also apparent in the modern (Holocene) setting: while the narrow platforms carved into the headlands host small beaches (e.g., Figure $\mathbf{4 A}$ and Figure HB in Normand et al., 2019a), bays host successions of beach ridges extending over several kilometers.

\section{Differential Erosion}

In the Makran, differential erosion between resistant sandstone and soft marl is a key factor in shaping of the current coastal geomorphology. The topography at the coastline is a direct reflection of the distribution of bedrock lithology, which is itself strongly influenced by local downfaulting of Pliocene blocks. Positive relief along the Makran coast occurs where resistant sandstones outcrop. The flat coastal plain is leveled by surficial degradation of the soft Upper Miocene marls during strong rain events. A prime example of differential erosion is the Chabahar headland. As reported in this study, the headland is bordered by normal faults and therefore is a downfaulted block. However, counter intuitively, the footwall is eroded, whereas the hanging wall is preserved (Figure 3).
Following these principles, bay beaches can evolve into the isolated platform observed along the Makran coast (Figure 4F). While a solidified beach is resistant to erosion, the erodible nature of the surrounding paleo coastal plain has contributed, together with tectonic uplift, to create a topographic anomaly below the marine terrace deposits by differential erosion (Figures 7E,F, 9). One of the best illustrations of these effects is seen in the Pasabander area. In this region, breached terraces with marl bedrock are efficiently eroded down to base level leaving isolated terrace remnants overlooking the coastal plain, bounded by vertical cliffs on both the seaward and landward sides (Figures 4D,F, 8G, 10B). Water runoff on the terraces' surfaces preferentially erode where sandy deposit are thinnest (e.g., swales between beach ridges and parallel to lineations), forming fingerlike morphologies (Figures 4D, 8C,G). Differential erosion also explains the scarcity of fine-grained lagoonal deposits (with low preservation potential) in the marl-type terraces compared to the sedimentary successions observed in Holocene bay beaches.

As a consequence of their soft bedrock, marl-type terraces seem to be much more ephemeral than the sandstone-type. This is reflected by dating results presented in Normand et al. (2019d) (note that data are exclusively from Iranian marine terrace sequences). For example, sandstone-type terraces were dated from MIS 5a ( 80 ka) to MIS 7 ( $\sim 200 \mathrm{ka})$, implying that terraces at higher altitudes within the same sequence might date back to MIS 17 ( $\sim 700 \mathrm{ka})$. Marl-type terraces were dated to as young as MIS $3 \mathrm{a}(\sim 30 \mathrm{ka})$ up to MIS $5 \mathrm{a}$, implying that the highest terraces from those sequence range back to a maximum of MIS $5 \mathrm{e}(\sim 125 \mathrm{ka})$. Moreover, the highest marl-type terraces are isolated remnants of less than a square kilometer, compared to their "young" equivalents (MIS 3 to MIS 5a), which are extensive (e.g., Konarak T1 (MIS 5a): $16 \mathrm{~km}^{2}$, Gurdim T1 (MIS 5a): $13 \mathrm{~km}^{2}$, Pasabander T2 (MIS3c): $15 \mathrm{~km}^{2}$ ) (Normand et al., 2019d; Figure 10). Some modern bay beaches are even more extensive, though it is difficult to predict how much of their original sizes will be preserved as a marine terrace in the next highstand. Surficial erosion plays the major role in the degradation of the landward side of the terraces. As long as the terrace deposits is preserved, erosion of the terrace surface is difficult. However, as soon as the underlying marl is exposed by a breach in the deposit (e.g., a gully), the degradation of the surface accelerates. On the seaward side, wave attack at the base of the marl cliffs (where any vertical protective effect of a sandstone cap is absent), can rapidly degrade marl-type terraces. Though, fallen debris of terrace deposits is expected to delay coastal retreat in function of the resistance (induration) of this deposit and its thickness (i.e., the volume of fallen blocks).

When erosion is significant, a distinction needs to be made between rock uplift rates and surface uplift rates (England and Molnar, 1990). The first is the uplift rate of a rock body relative to a fixed point (e.g., due to tectonic forces). The second corresponds to uplift of Earth's surface (i.e., the interface between rock and air) and as such, considers erosion as a factor counteracting uplifting forces. The sediments of the Mmt were deposited close to sea level; they can therefore be used as markers for relative sea level change. Surface uplift rates below the capping deposits is equivalent to rock uplift, as the erosion 


\section{A Coastal evolution}
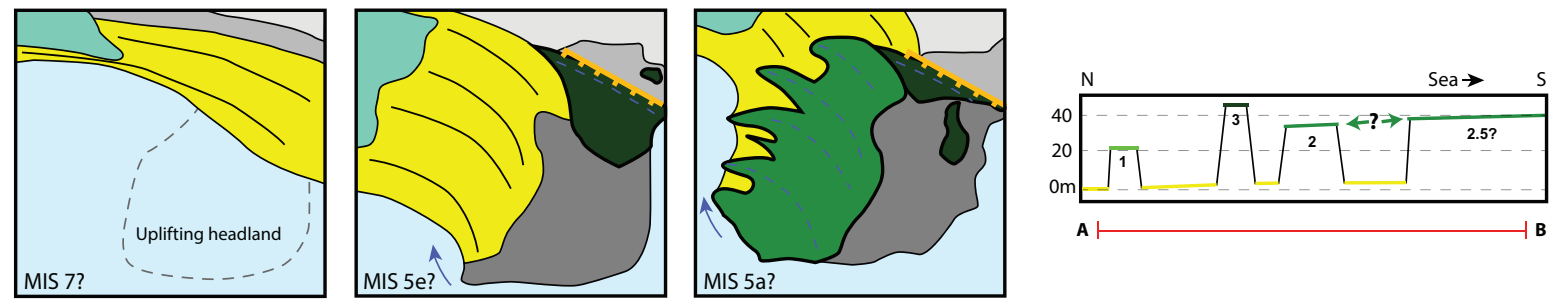

Time
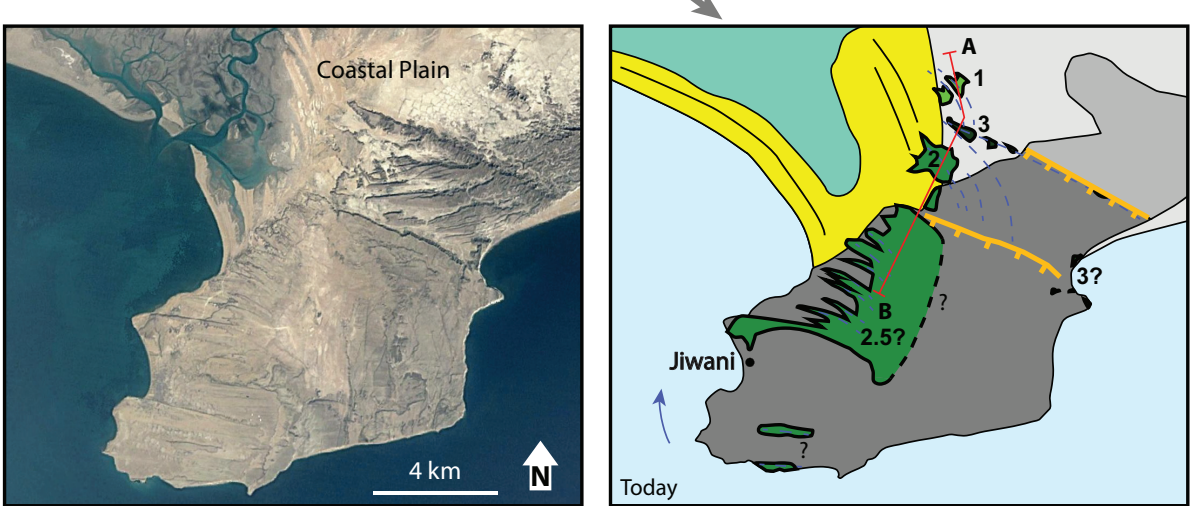

B

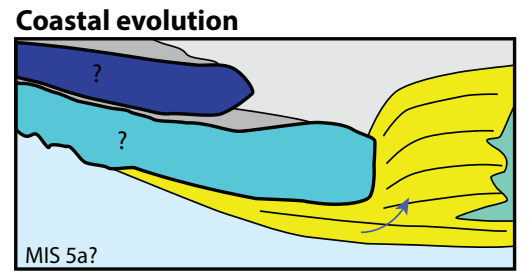

MIS 5a?
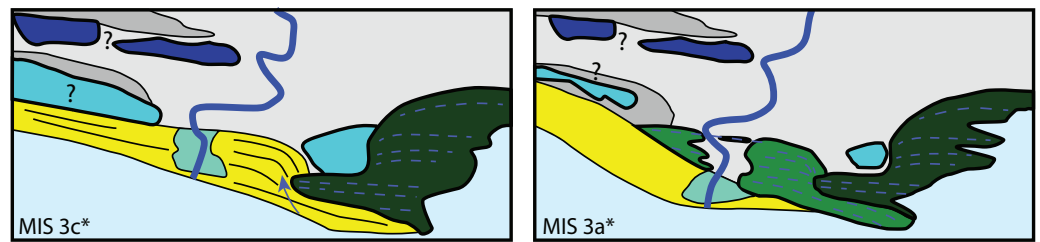

Time
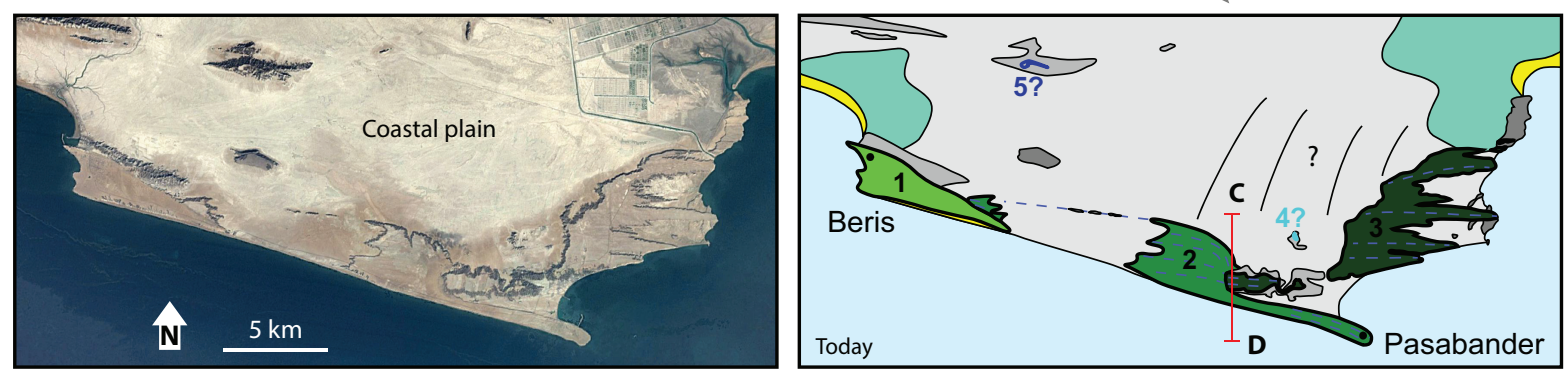

Legend:
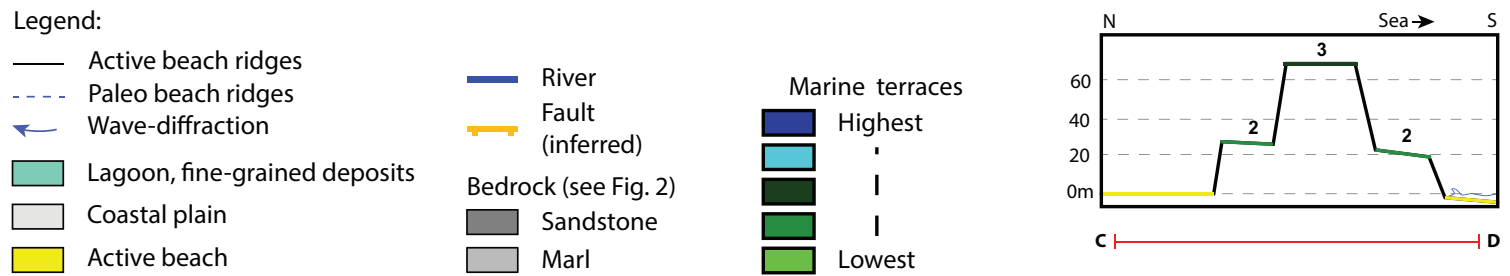

FIGURE 10 | Two examples of Makran coastal evolution models over several sea-level highstands. The presence of headlands in the form of sandstone-dominated bedrock outcrops (Jiwani) or uplifted marine terraces (Pasabander) has favored the creation of crenulated bay beaches, later uplifted into marine terraces, which in turn act as headlands. (A) Jiwani terraces coastal evolution (highstand ages are inferred, since no dating results are available in this region). Current situation is presented with a satellite image (Landsat) and interpreted terrace map. The topographic profile (A-B) through the terraces shows a landward terrace sequence and not the expected classical seaward staircase-like profile. (B) Pasabander terraces coastal evolution. *Ages from OSL dating (Normand et al., 2019d). Current situation is presented with a satellite image (Landsat), interpreted terrace map [modified after Normand et al. (2019d)] and topographic profile C,D. 
rate of the solidified beach deposit is close to zero. However, in the coastal plain near the paleobeach, erosive forces have completely counterbalanced rock (tectonic) uplift rates, implying surface uplift rates close to zero (Figure 9). In fact, we can infer marl erosion rates by knowing rock uplift rates from the dating results on the marine terraces (Normand et al., 2019d).

\section{Coastal Evolution Patterns}

The sandstone-dominated rocky headlands persistently host the coastline through several sea-level highstands as they slowly uplift, developing classical staircase pattern of terraces (Figure 4A). Marl-type terraces, are more ephemeral but are involved into a positive feedback process during one or two successive highstands. After being uplifted into marine terraces, paleo bay beaches can act as protruding headlands (e.g., Figures 7G, 8E, 10B), favoring the formation of future sandy bay beaches in the adjacent protected bays (Figure 10). Ultimately, these sandy beaches will in turn become marine terraces, whereas older terraces will erode and the process will repeat.

This behavior can explain the occurrence of lateral or even landward terrace sequences (profiles in Figure 10). The classical marine terrace sequence pattern is that younger terraces are situated seaward of older ones, with terrace limits being roughly parallel to the current coastline; this is the case for Makran sandstone-type terraces. However, Holocene sandy morphologies such as crenulated beaches and tombolos (e.g., Gurdim, Figure 1C) are situated laterally or northward (i.e., landward) of headlands / marine terraces, setting the stage for the occurrence of what we call "landward terrace sequences," where the youngest terraces are situated in a landward position relative to the oldest (Figure 10). In Jiwani for example, we explain this by the formation of crenulated beaches in the lee of the Jiwani headland during successive highstands, as hinted by the curved lineations visible on these Pleistocene terraces as well as the morphologies of Holocene beach ridges in Jiwani bay (Figure 10A). The Supplementary Material B provides some examples of interpreted coastal evolution in different areas of the Makran coast.

\section{CONCLUSION}

Our depositional model for the Makran marine terraces based on the terrace morphology, sedimentology and observation of current (Holocene) coastal setting is the following: Wavecut erosion and platform development occurs during the early stages of a sea-level highstand. This is followed by the deposition of prograding beaches above the eroded platform during the sea-level stillstand and the beginning of the ensuing relative sea-level fall. The deposition of an extensive sedimentary succession above the wave-cut surface is favored by the high sediment input from the eroding accretionary prism. As such, the formation of the Makran marine terraces result from the combined effort of erosion and sedimentation.

The presence of punctuated protruding headlands along the Makran coast is attributed to differential erosion between soft and hard rock. We divide the Makran marine terraces in two groups based on their bedrock lithology. The first developed on locally downfaulted Pliocene sandstone-dominated blocks, outcropping at the coastline, and have a classical staircase morphology. The second are uplifted indurated bay beaches, originally formed on soft marl bedrock between protruding headlands. They are now found as flat-topped topographic anomalies as surrounding uncovered fine-grained bedrock is rapidly eroded down to the coastal plain level. As old beaches are uplifted into headlands, they influence the formation of the future generations of beaches during the ensuing highstand.

Our study shows that the morphology of the Makran coast was strongly modulated by competing interactions between three main factors. (1) Tectonic forces, providing regional relative sealevel fall (together with eustatism), while juxtaposing units of markedly different erodability to the same structural level by faulting. (2) Surface processes such as differential erodability, responsible for the isolation of protruding headlands and the high sedimentary input at the Makran coast. (3) Coastal processes, permitting the wave-erosion of marine terraces and the development of extensive beaches.

\section{DATA AVAILABILITY}

All datasets generated for this study are included in the manuscript and/or the Supplementary Files.

\section{AUTHOR CONTRIBUTIONS}

$\mathrm{RN}$ conducted the fieldwork, wrote the manuscript, and created the figures. GS accompanied RN in the fieldwork and provided substantial inputs on the tectonic and geodynamic aspects. AB provided his inputs on the Iranian geology and tectonics, and organized field campaigns.

\section{FUNDING}

This work was funded by the Swiss National Science Foundation, project No. 200021_155904.

\section{ACKNOWLEDGMENTS}

We thank Kevin Pedoja for his inputs and all the fruitful and interesting discussions. We are also grateful to Reza Ensani, Feisal Arjomandi, Nurrudin Mazarzehi, Yousef Adeeb, and Gholamreza Hosseinyar for helping us with logistics in Iran and accompanying us in the fieldwork.

\section{SUPPLEMENTARY MATERIAL}

The Supplementary Material for this article can be found online at: https://www.frontiersin.org/articles/10.3389/feart.2019. 00186/full\#supplementary-material 


\section{REFERENCES}

Anderson, R. S., Densmore, A. L., and Ellis, M. A. (1999). The generation and degradation of marine terraces. Basin Res. 11, 7-19. doi: 10.1046/j.1365-2117. 1999.00085.x

Bird, E. (2000). Coastal Geomorphology, an Introduction. Hoboken, NY: Wiley.

Bourget, J., Zaragosi, S., Ellouz-Zimmermann, S., Ducassou, E., Prins, M. A., Garlan, T., et al. (2010). Highstand vs. lowstand turbidite system growth in the Makran active margin: imprints of high-frequency external controls on sediment delivery mechanisms to deep water systems. Mar. Geol. 274, 187-208. doi: 10.1016/j.margeo.2010.04.005

Byrne, D. E., Sykes, L. R., and Davis, D. M. (1992). Great thrust earthquakes and aseismic slip along the plate boundary of the makran subduction zone. J. Geophys. Res. Earth 97, 449-478. doi: 10.1029/91JB02165

Catuneanu, O., Galloway, W. E., Kendall, C. G. S. C., Miall, A. D., Posamentier, H. W., Strasser, A., et al. (2011). Sequence stratigraphy: methodology and nomenclature. Newsletters Stratigr. 44/3, 173-245. doi: 10.1127/0078-0421/ 2011/0011

Dietz, R. (1963). Wave-base, marine profile of equilibrium, and wave-built terraces: a critical appraisal. Geol. Soc. Am. Bull. 74, 971-990.

Dolati, A., and Burg, J.-P. (2013). "Preliminary fault analysis and paleostress evolution in the Makran Fold-and-Thrust Belt in Iran," in Lithosphere Dynamics and Sedimentary Basins: The Arabian Plate and Analogues, eds K. Al Hosani, F. Roure, R. Ellison, and S. Lokier, (Berlin: Springer), 261-277. doi: 10.1007/9783-642-30609-9_13.

Dupré, W. R. (1984). Reconstruction of paleo-wave conditions during the Late Pleistocene from marine terrace deposits, Monterey Bay, California. Mar. Geol. 60, 435-454. doi: 10.1016/0025-3227(84)90161-0

Ellouz-Zimmermann, N., Lallemant, S. J., Castilla, R., Mouchot, N., Leturmy, P., Battani, A., Buret, C., et al. (2007). "Offshore Frontal part of the Makran Accretionary Prism: The Chamak Survey (Pakistan)," in Thrust belts and Foreland Basins, eds O. Lacombe, F. Roure, J. Lavé, and J. Vergés (Springer: Berlin), 351-366. doi: 10.1007/978-3-540-69426-7_18.

England, P., and Molnar, P. (1990). Surface uplift, uplift of rocks, and exhumation of rocks. Geology 18, 1173-1177.

Falcon, N. L. (1947). Raised beaches and terraces of the Iranian Makran coast. Geogr. J. 109, 149-151.

Farhoudi, G., and Karig, D. E. (1977). Makran of Iran and Pakistan as an active arc system. Geology 5, 664-668.

Frohling, E., and Szeliga, W. (2016). GPS constraints on interplate locking within the Makran subduction zone. Geophys. J. Int. 205, 67-76. doi: 10.1093/gji/ ggw001

Gharibreza, M. (2016). Evolutionary trend of paleoshorelines in the Coastal Makran zone (Southeast Iran) since the mid-Holocene. Quat. Int. 392, 203-212. doi: 10.1016/j.quaint.2015.06.030

Ghorashi, M. (1978). Late Cainozoic faulting in S.E. Iran. Ph.D. thesis, University College London, London.

Gilbert, G. (1890). Lake Bonneville. Washington, DC: U.S. Government Printing Office.

Grando, G., and McClay, K. (2007). Morphotectonics domains and structural styles in the Makran accretionary prism, offshore Iran. Sediment. Geol. 196, 157-179. doi: 10.1016/j.sedgeo.2006.05.030

Harms, J. C., Cappel, H. N., and Francis, D. C. (1984) "The Makran Coast of Pakistan: It's Stratigraphy and Hydrocarbon Potential," in Marine Geology and Oceanography of Arabian Sea and Coastal Pakistan, eds B. U. Haq, and J. D. Milliman, (New York. NY: Van Nostrand Reinhold Company Inc.)

Harrison, J. V. (1941). Coastal makran: discussion. Geogr. J. 97, 1-15.

Hurst, M. D., Barkwith, A., Ellis, M. A., Thomas, C. W., and Murray, A. B. (2015). Exploring the sensitivities of crenulate bay shorelines to wave climates using a new vector-based one-line model. J. Geophys. Res. Earth Surf. 120, 2586-2608.

Jara-Muñoz, J., and Melnick, D. (2015). Unraveling sea-level variations and tectonic uplift in wave-built marine terraces, Santa María Island, Chile. Quat. Res. 83, 216-228. doi: 10.1016/j.yqres.2014. 10.002

Khan, M. A., Bendick, R., Bhat, M. I., Bilham, R. G., Kakar, D. M., Khan, S. F., et al. (2008). Preliminary geodetic constraints on plate boundary deformation on the western edge of the Indian plate from TriGGnet (Tri-University GPS Geodesy Network). J. Himal. Earth Sci. 41, 71-87.
Lajoie, K. R. (1986). “Coastal Tectonics," in Active Tectonics: Impact on Society, ed. R. Wallace, (Washington, DC: National Academy Press).

Leggett, J. K., and Platt, J. P. (1984). "Structural Features of the Makran Forearc on Landsat Imagery," in Marine Geology and Oceanography of Arabian Sea and Coastal Pakistan, eds B. U. Haq, and J. D. Milliman, (New York, NY: Van Nostrand Reinhold Company Scientific and Academic Editions).

Limber, P. W., and Murray, A. B. (2011). Beach and sea-cliff dynamics as a driver of long-term rocky coastline evolution and stability. Geology 39, 1147-1150. doi: 10.1130/G32315.1

Limber, P. W., Murray, A. B., Adams, P. N., and Goldstein, E. B. (2014). Unraveling the dynamics that scale cross-shore headland relief on rocky coastlines: 1. Model development. J. Geophys. Res. Earth Surf. 119, 854-873. doi: 10.1002/ 2013JF002950

Little, R. D. (1972). Terraces of the Makran Coast of Iran and parts of West Pakistan. Ph.D. thesis, University of Southern California, California.

Masson, F., Anvari, M., Djamour, Y., Walpersdorf, A., Tavakoli, F., Daignières, M., et al. (2007). Large-scale velocity field and strain tensor in Iran inferred from GPS measurements: new insight for the present-day deformation pattern within NE Iran. Geophys. J. Int. 170, 436-440. doi: 10.1111/j.1365-246X.2007.03477.x

McCall, G. J. H., and Kidd, R. G. (1982). "The Makran, Southeastern Iran: the anatomy of a convergent plate margin active from Cretaceous to Present," in Trench-fore-arc Geology: Sedimentation and Tectonics of Modern and Ancient Plate Margins, ed. J. K. Leggett (London: Special Publication).

Normand, R., Simpson, G., and Bahroudi, A. (2019a). Data for: pleistocene coastal evolution of the Makran subduction zone. Zenodo

Normand, R., Simpson, G., and Bahroudi, A. (2019b). Extension at the Coast of the Makran Subduction zone (Iran): Terra Nova. (in press). doi: 10.1111/ter.12419

Normand, R., Simpson, G., Herman, F., Biswas, R. H., and Bahroudi, A. (2019c). Holocene sedimentary record and coastal evolution in the Makran subduction zone (Iran). Quaternary 2:21. doi: 10.3390/quat2020021

Normand, R., Simpson, G., Herman, F., Biswas, R. H., Bahroudi, A., and Schneider, B. (2019d). Dating and morpho-stratigraphy of uplifted marine terraces in the Makran subduction zone (Iran). Earth Surf. Dyn. 7, 321-344. doi: 10.5194/ esurf-7-321-2019

Page, W. D., Alt, J. N., Cluff, L. S., and Plafker, G. (1979). Evidence for the recurrence of large-magnitude earthquake along the Makran coast of Iran and Pakistan. Tectonophysics 52, 533-547. doi: 10.1016/0040-1951(79)90269-5

Pedoja, K., Husson, L., Johnson, M. E., Melnick, D., Witt, C., and Pochat, S. E., et al. (2014). Coastal staircase sequences reflecting sea-level oscillations and tectonic uplift during the Quaternary and Neogene. Earth Sci. Rev. 132, 13-38. doi: 10.1016/j.earscirev.2014.01.007

Platt, J. P., and Leggett, J. K. (1986). Stratal extension in thrust footwalls, makran accretionary prism: implications for thrust tectonics. Am. Assoc. Pet. Geol. Bull. 70, 191-203.

Saket, A., and Etemad-shahidi, A. (2012). Wave energy potential along the northern coasts of the Gulf of Oman, Iran. Renew. Energy 40, 90-97. doi: 10.1016/j. renene.2011.09.024

Samadian, M. R., Ghomashi, A., Chaichi, Z., Eshraghi, S. A., Kholghi, M. H., Abdollahi, M. R., et al. (2004). Geological map of Iran 1:100'000. Tehran: Geological Survey of Iran.

Samadian, M. R., Ghomashi, A., Jamshidi, K., Afsharianzadeh, A., Sharifian, M. I., Abdolahi, M. R., et al. (1994). Geological map of Iran 1:100'000. Tehran: Geological Survey of Iran.

Samadian, M. R., Ghomashi, A., Mohebbi, A. R., Jafarian, M. B., Abdoli, M., and Ahmadzadeh Heravi, M. (1996). Geological map of Iran 1:100'000. Tehran: Geological Survey of Iran.

Sanlaville, P., Besenval, R., Evin, J., and Prieur, A. (1991). Evolution de la région littorale du Makran pakistanais à l'Holocène. Paléorient 17, 3-18. doi: 10.3406/ paleo.1991.4536

Shah-Hosseini, M., Ghanavati, E., Morhange, C., Naderi Beni, A., Lahijani, H. A., and Hamzeh, M. A. (2018). The evolution of Chabahar beach ridge system in SE Iran in response to Holocene relative sea level changes. Geomorphology 318, 139-147. doi: 10.1016/j.geomorph.2018.06.009

Snead, R. J. (1967). Recent morphological changes along the coast of West Pakistan. Ann. Assoc. Am. Geogr. 57, 550-565. doi: 10.1111/j.1467-8306.1967.tb00 621.x

Snead, R.J. (1993). "Uplifted Marine Terraces along the Makran coast of Pakistan and Iran," in Himalaya to the Sea, ed. J. F. J. Shroder (London: Routledge). 
Stiffe, A. W. (1874). On the Mud-craters and geological structure of the mekran coast. Q. J. Geol. Soc. 30, 50-53. doi: 10.1144/GSL.JGS.1874.030.01-04.24

Tamura, T. (2012). Beach ridges and prograded beach deposits as palaeoenvironment records. Earth Sci. Rev. 114, 279-297. doi: 10.1016/j. earscirev.2012.06.004

Trenhaile, A. (2014). Modelling the effect of pliocene-quaternary changes in sea level on stable and tectonically active land masses. Earth Surf. Process. Landforms 39, 1221-1235. doi: 10.1002/esp.3574

Trenhaile, A. (2016). Earth-science reviews rocky coasts - their role as depositional environments. Earth Science Rev. 159, 1-13. doi: 10.1016/j.earscirev.2016.05.001

Trenhaile, A. S. (2000). Modeling the development of wave-cut shore platforms. Mar. Geol. 166, 163-178. doi: 10.1016/S0025-3227(00)00013-X

Trenhaile, A. S. (2002). Modeling the development of marine terraces on tectonically mobile rock coasts. Mar. Geol. 185, 341-361. doi: 10.1016/S0025$3227(02) 00187-1$

Trenhaile, A. S. (2018). Modelling the effect of rising sea level on beaches with resistant foundations. Mar. Geol. 395, 1-13. doi: 10.1016/j.margeo.2017.09.004

Uchupi, E., Swift, S. A., and Ross, D. A. (2002). Morphology and late quaternary sedimentation in the gulf of oman basin. Mar. Geophys. Res. 23, 185-208. doi: 10.1023/A:1022408106382

Valvo, L. M., Murray, A. B., and Ashton, A. (2006). How does underlying geology affect coastline change? An initial modeling investigation. J. Geophys. Res. 111:F02025. doi: 10.1029/2005JF000340
Vernant, P., Nilforoushan, F., Hatzfeld, D., Abbassi, M. R., Vigny, C., Masson, F., et al. (2004). Present-day crustal deformation and plate kinematics in the Middle East constrained by GPS measurements in Iran and northern Oman. Geophys. J. Int. 157, 381-398. doi: 10.1111/j.1365-246X.2004.02222.x

Vita-Finzi, C. (1980). 14C dating of recent crustal movements in the persian gulf and iranian makran. Radiocarbon 22, 763-773. doi: 10.1017/ S0033822200010134

White, R. S., and Louden, K. E. (1982). “The Makran continental margin: structure of a thickly sedimented convergent plate boundary," in Studies in Continental Margin Geology, eds J. S. Watkins, and C. L. Drake (Tulsa, OK: American Association of Petroleum Geologists).

Yasso, W. E. (1965). Plan geometry of headland-bay beaches. J. Geol. 73, 702-714. doi: $10.1086 / 627111$

Conflict of Interest Statement: The authors declare that the research was conducted in the absence of any commercial or financial relationships that could be construed as a potential conflict of interest.

Copyright $(\odot 2019$ Normand, Simpson and Bahroudi. This is an open-access article distributed under the terms of the Creative Commons Attribution License (CC BY). The use, distribution or reproduction in other forums is permitted, provided the original author(s) and the copyright owner(s) are credited and that the original publication in this journal is cited, in accordance with accepted academic practice. No use, distribution or reproduction is permitted which does not comply with these terms. 